\title{
ULTRASTRUCTURAL RELATIONSHIPS BETWEEN DECIDUA, TROPHOBLAST AND LYMPHOCYTES AT THE BEGINNING OF HUMAN PREGNANCY
}

\author{
M. TEKELIOĞLU-UYSAL,* R. G. EDWARDS† AND H. A. KISNIȘC̣I $\ddagger$ \\ Departments of ${ }^{*}$ Histology-Embryology and $\ddagger$ Gynecology-Obstetrics, \\ Faculty of Medicine, The Hacettepe University, Ankara, Turkey, and \\ $\dagger$ Physiological Laboratory, Cambridge
}

(Received 17th Fune 1974)

\begin{abstract}
Summary. Between the 20th and 40th day of pregnancy, human decidual cells in the endometrial connective tissue come into direct contact with the trophoblastic cells eroding the stromal tissue. Fibrillar deposits of maternal origin were randomly distributed between the maternal and fetal sites and did not form a continuous barrier.

Structural features were prominent in the maternal and embryonic cells. Large decidual cells were intermingled with trophoblastic cells, and there was little intercellular material. Small developing decidual cells arose around the maternal precapillary arterioles and capillaries and were closely accompanied by lymphocytes. Fully developed decidual cells exhibited a fine structure characteristic of a state of active secretion, and trophoblastic cells gave structural indications of producing protein.

The aggregates of decidual and trophoblastic cells in the human endometrium during early pregnancy ('deciduotrophoblastic complex') may function as a local humoral regulator releasing chemical factors and partaking in the establishment of immunological privilege at implantation.
\end{abstract}

\section{INTRODUCTION}

The examination of young human embryos and placentae by light microscopy has indicated that the peripheral cells of the trophoblastic shell are closely intermingled with the active decidual cells of the endometrial connective tissue (Hamilton \& Boyd, 1960). The basic ultrastructural characteristics of human decidual and trophoblastic cells have been established by examinations of basal plate, anchoring villi and parietal decidua of human placentae in the first trimester and at the end of gestation (Wynn, 1967a; Enders, 1968; Lawn, Wilson \& Finn, 1971). The ultrastructural relationship between decidual and trophoblastic elements at the beginning of trophoblastic invasion has not been examined and is the aim of the present study. 


\section{MATERIALS AND METHODS}

Tissues were collected from twelve women between the 20th and 40th day of pregnancy. The last ovulation date before the beginning of pregnancy was taken as the age of conception. The mean age of the women was 28 years; there was no evidence of infection in any of them and none was subjected to abortion for gynaecological reasons. Curettage was applied during surgical intervention in order to avoid the mechanical destruction of tissue as far as possible.

Samples collected by curettage were viscous, easily damaged and difficult to process and post-mortem changes were inevitable in some of the preparations. After prefixing for $2 \mathrm{hr}$ in $2.5 \%$ glutaraldehyde solution buffered with phosphate to $\mathrm{pH} 6.9$ to $7 \cdot 1$, all specimens were then washed overnight in cold sucrose in the same phosphate buffer and were postfixed in $1 \%$ osmium tetroxide in phosphate buffer for $1 \mathrm{hr}$ (Millonig, 1962). They were later dehydrated in graded alcohols, stained en bloc in a saturated solution of uranyl acetate in $70 \%$ alcohol during dehydration, and embedded in Araldite. An LKB Ultrotome III was used for sectioning. Thick sections were stained with $1 \%$ aqueous toluidine blue and examined for topographic orientation. Silver-tone thin sections were collected on uncoated grids and stained in alkaline lead citrate (Reynolds, 1963).

Carl Zeiss 9A, Siemens 6B and AEI 801 type electron microscopes were used in examining and photographing the thin sections.

\section{RESULTS}

In the deciduotrophoblastic zone, large fully-developed decidual cells were observed in groups of two or three intermingled among the trophoblastic cells of the embryo. Extensions from the trophoblastic cells appeared to be sandwiched between the decidual cells (Pl. 1, Fig. 1). These aggregates of decidual and trophoblastic cells will be called 'deciduotrophoblastic complexes'. Fibrillar deposits were distributed randomly around the deciduotrophoblastic complexes (Pl. 2, Fig. 2).

Decidual and trophoblastic cells were distinguished by their distinct fine structure. Fully developed decidual cells were large and clear with few club-like extensions, and they were not surrounded by an external lamina or glycocalyx. The cell membrane exhibited local thickenings, and tiny cytoplasmic extrusions were frequent along the cell membrane. The nucleus was located eccentrically, was slightly indented, and had a fine chromatin content and a well-developed nucleolus. The Golgi complex was large with numerous profiles of cisternae and transverse sections of cisternae seen in vesicle form. Short profiles of tubuli of a granular endoplasmic reticulum were already established, and were distributed throughout the cytoplasm. Small and delicate mitochondria were scattered among the other organelles. Free ribosomes and polysomes were numerous. There were no structural signs of the deposition of any secretion product in the cytoplasm of the fully developed decidual cell (Pl. 3, Fig. 3).

By contrast, trophoblastic cells were identified as darker cells with numerous thick and long extensions. These cells also showed no indication of a surrounding 
external lamina. The nucleus was large and considerably indented, the chromatin was dense, and a well-developed nucleolus was present. Tubules of the endoplasmic reticulum (i.e. profiles of the flattened cisternae of the endoplasmic reticulum) were enlarged in cisternal forms (see Fawcett, 1966), and possessed a fine granular content. Thick bundles of intracellular filaments, together with large ovoid mitochondria and glycogen aggregates, were packed among the cisternal elements of the endoplasmic reticulum. Numerous ribosomes were noticed in the cytoplasmic matrix. Rounded inclusions, apparently lipid or lipid droplets, were located in the cytoplasm, surrounded by glycogen granules (Pl. 3, Fig. 4).

In the deciduotrophoblastic complexes, the narrow interface between decidual and trophoblastic cells contained no structural element functioning as a mechanical barrier; some fine filaments were scattered between them (Pl. 4, Fig. 5). Fine cytoplasmic protrusions from decidual cells were not infrequently observed approaching the surface of trophoblastic cells and filling the narrow space between their surfaces (Pl. 4, Fig. 6).

Small developing decidual cells were frequently encountered, apart from the deciduotrophoblastic complexes, clustered around the small vessels and among the other cell types of the endometrial connective tissue (Pl. 5, Fig. 7). These decidual cells exhibited structural properties similar to those of the larger decidual cells, except for their smaller size and a rather narrow rim of cytoplasm surrounding the nucleus. Small decidual cells were arranged loosely together, with a constant space around them. They were embedded in the fine granular matrix of the endometrial connective tissue free from fibrillar deposits. They also revealed a close structural connection with some other cells in the connective tissue, which were evidently lymphoblasts or small lymphocytes (Pl. 6, Fig. 8), the association often appearing to be very close indeed (Pl. 7, Figs 9 and 10). The peripheral cytoplasm of the small decidual cell displayed a variety of structural properties. Tiny club-like protrusions of the cytoplasm surrounded by membrane were observed along the membrane surface attached to the cell by thin stalks. Many of the protrusions were evidently detached from the cells and were found in the extracellular space, although this appearance may have been due to the plane of the section. Protein-coated and uncoated vesicles were visible near sites where the cell membrane was thickened. Profiles of the peripheral tubuli (or cisternae) of the granular endoplasmic reticulum were detected under the cell membrane adjacent to the protein-coated vesicles (Pl. 8, Fig. 11).

\section{DISCUSSION}

Observations on the fine structure and interrelationships between decidual cells, trophoblastic cells and lymphocytes during early human implantation have been made in the present study. The darker appearance of the trophoblastic cells of the deciduotrophoblastic complex was due to the high content of ribosomes and closely packed microfilaments. Large lipid droplets or granules in intimate association with the profiles of cisternae of the endoplasmic reticulum indicated the production of a substance in the cytoplasm assumed to be a lipo- 
or glycoprotein in nature, as histochemically confirmed by DallenbachHellweg \& Nette (1964). Further study is clearly needed on this point.

Decidual cells in the deciduotrophoblastic region evidently have an active rôle, for they exhibited distinct features of actively secreting cells such as a large Golgi complex and a well-developed granular endoplasmic reticulum scattered throughout the cytoplasm. The presence of coated and uncoated vesicles at the site of frequent thickenings of the cell membrane suggests that decidual cells are capable of extruding a protein or protein-like substance into the intercellular area. Extracellular matrices have been found between decidual cells; Wynn (1969) defined cells of the basal decidua of several species which probably secreted humoral substances, and such matrices have been found in human uteri during the first trimester (Lawn et al., 1971) and in rats (Tachi, Tachi \& Lindner, 1970). Our observations showed that neighbouring decidual cells were in close association before secretion began and some decidual cells in the human placenta evidently remain closely opposed at a later stage of pregnancy (Enders, 1968). The nature of these secretions or their rôle in nourishing the trophoblast or in conferring immunological protection on the embryo against a sensitized mother cannot yet be assessed.

Decidual and trophoblastic cells were observed in intimate association in the present work, although cytoplasmic fusion, such as occurs between the trophoblast and uterine epithelial cells in the rabbit (Enders \& Schlafke, 1971), was not observed. Studies on even earlier stages of pregnancy would be needed to find out if outgrowths from trophectoderm of human blastocysts (Steptoe,

\section{EXPLANATION OF PLATES 1 TO 4}

\section{PLATE 1}

FIG. 1. Detail of the human deciduotrophoblastic complex. An extension of a trophoblastic cell ( $\mathrm{Tr}$ ) is sandwiched between three large decidual cells (De). The cytoplasm of the decidual cells is pale, with short profiles of tubuli of granular endoplasmic reticulum and small delicate mitochondria. $\times 24,000$.

\section{PLATE 2}

FIG. 2. Human deciduotrophoblastic complex located in fibrillar material. A typical large decidual cell (De) is in close apposition with the extension of a trophoblastic cell (Tr) at its lower part (arrows). The trophoblastic cell extension is surrounded by two other decidual cell extensions $(x)$. Fibrillar material (Fi) is distributed outside the complex. $\times 16,000$.

\section{PLATE 3}

FIG. 3. A typical large human decidual cell exhibiting local thickenings along the cell membrane. An eccentric nucleus (N), a highly-developed Golgi complex (Go) and frequent short profiles of the tubuli of granular endoplasmic reticulum with delicate small mitochondria $(\mathrm{M})$ are noticeable in the cytoplasm. $\times 14,000$.

FIG. 4. Perinuclear region of a human trophoblastic cell surrounded by club-like decidual extensions $(x)$ and fibrillar material $(\mathrm{Fi})$. The cytoplasm of the trophoblastic cell is dark due to the existence of closely packed fine filaments and glycogen aggregates between the cisternal profiles of the tubuli of endoplasmic reticulum. Lipid inclusions $(\mathrm{Li})$ are detectable. Note that the nucleus $(\mathrm{N})$ is highly indented with well-developed nucleoli. $\times 18,500$.

\section{PLATE 4}

FIG. 5. Human deciduotrophoblastic interface between a decidual (De) and trophoblastic cell (Tr). Intercellular material is sparse and discontinuous. The decidual cell has open cytoplasmic connections with the intercellular area at the points where the cell membrane is interrupted (arrows). $\times 32,000$.

Fra. 6. Fine decidual cytoplasmic protrusions $(x)$ are seen filling the narrow intercellular area between human decidual (De) and trophoblastic cells ( $\mathrm{Tr}$ ). A distinct border is difficult to differentiate in this deciduotrophoblastic apposition. $\times 32,000$. 


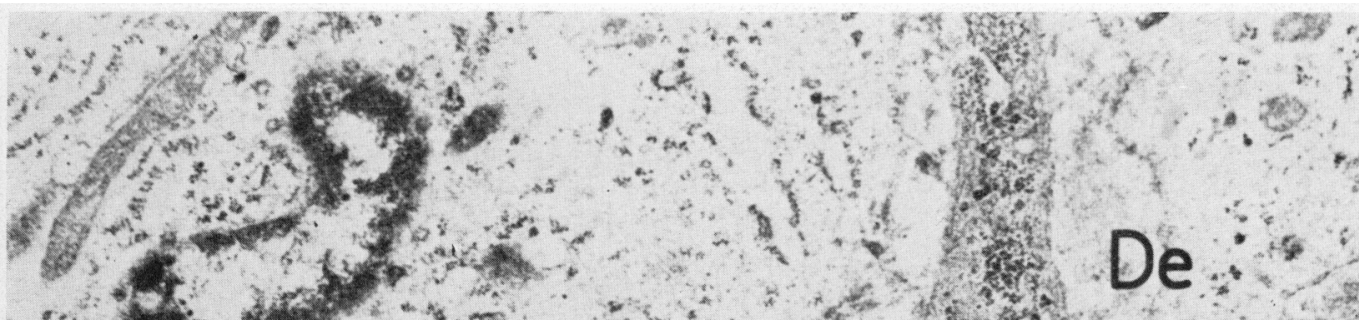

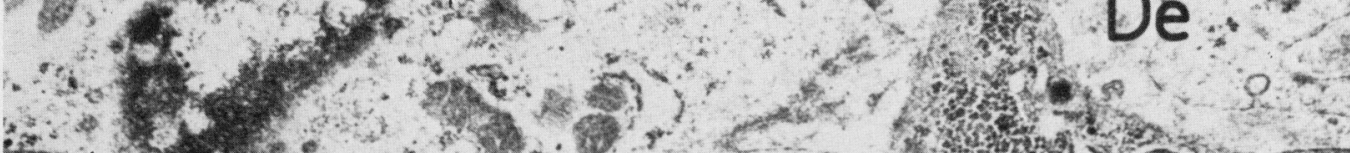

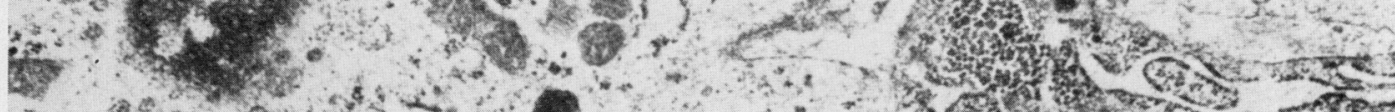

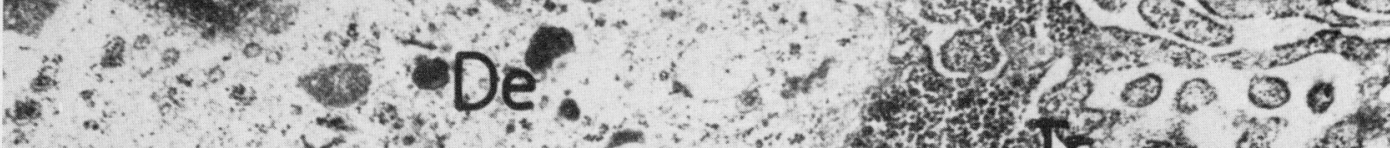

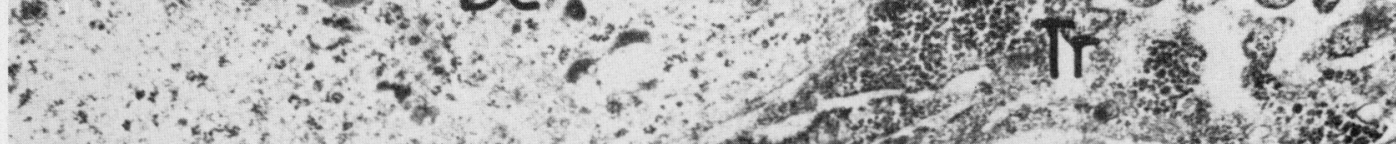

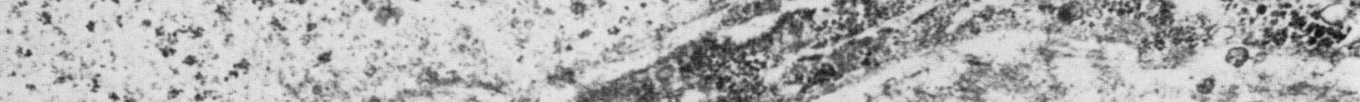

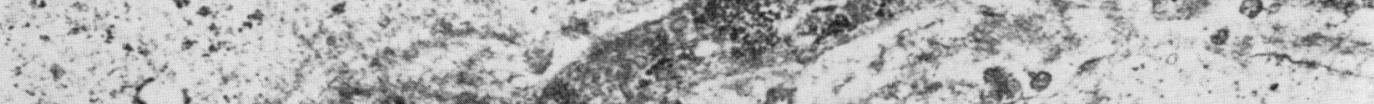

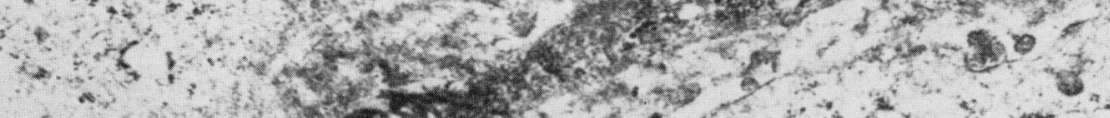
(2) a (5)

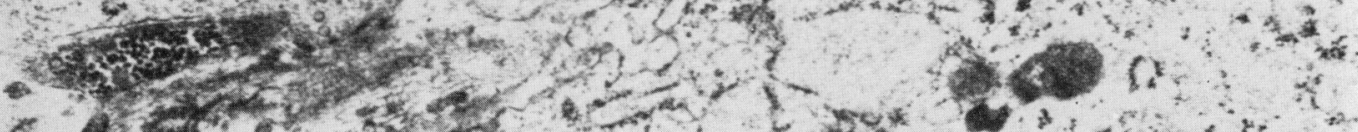

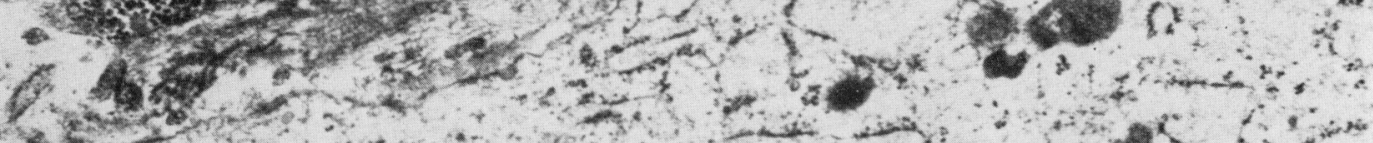

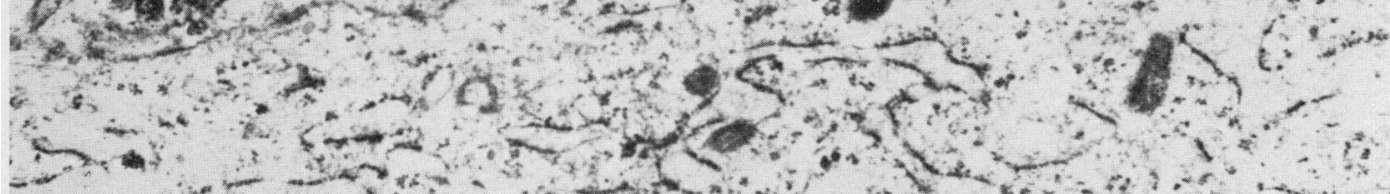

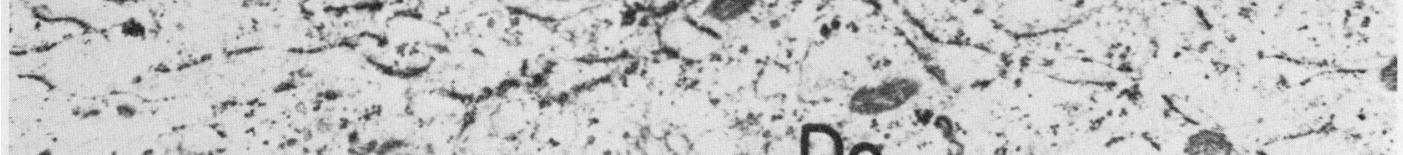

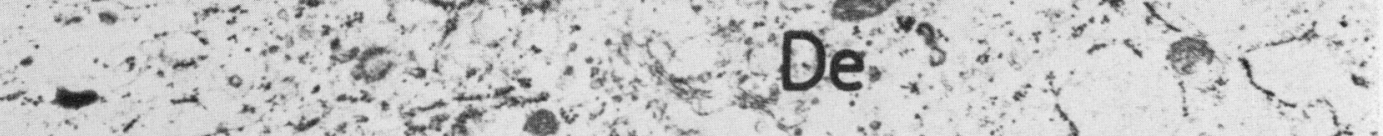
4.

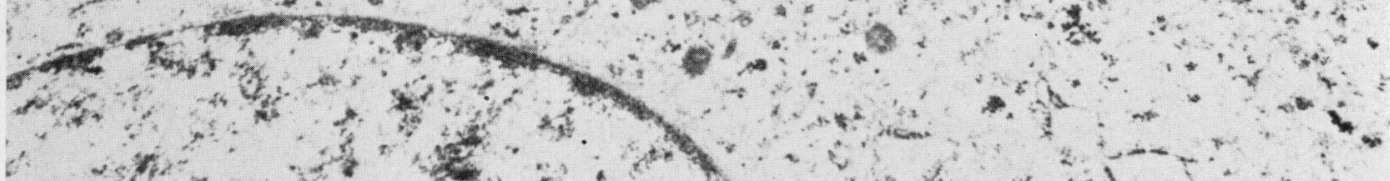

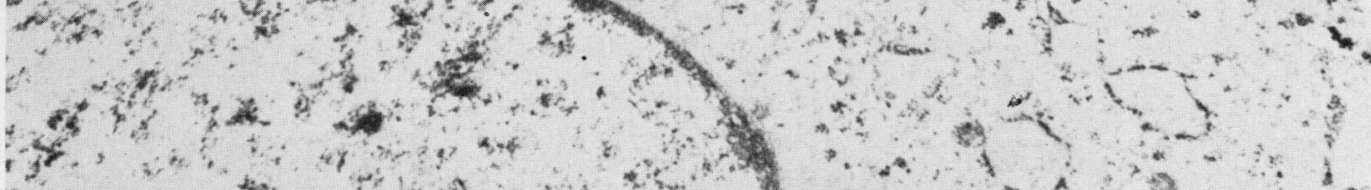
(1) ;" 


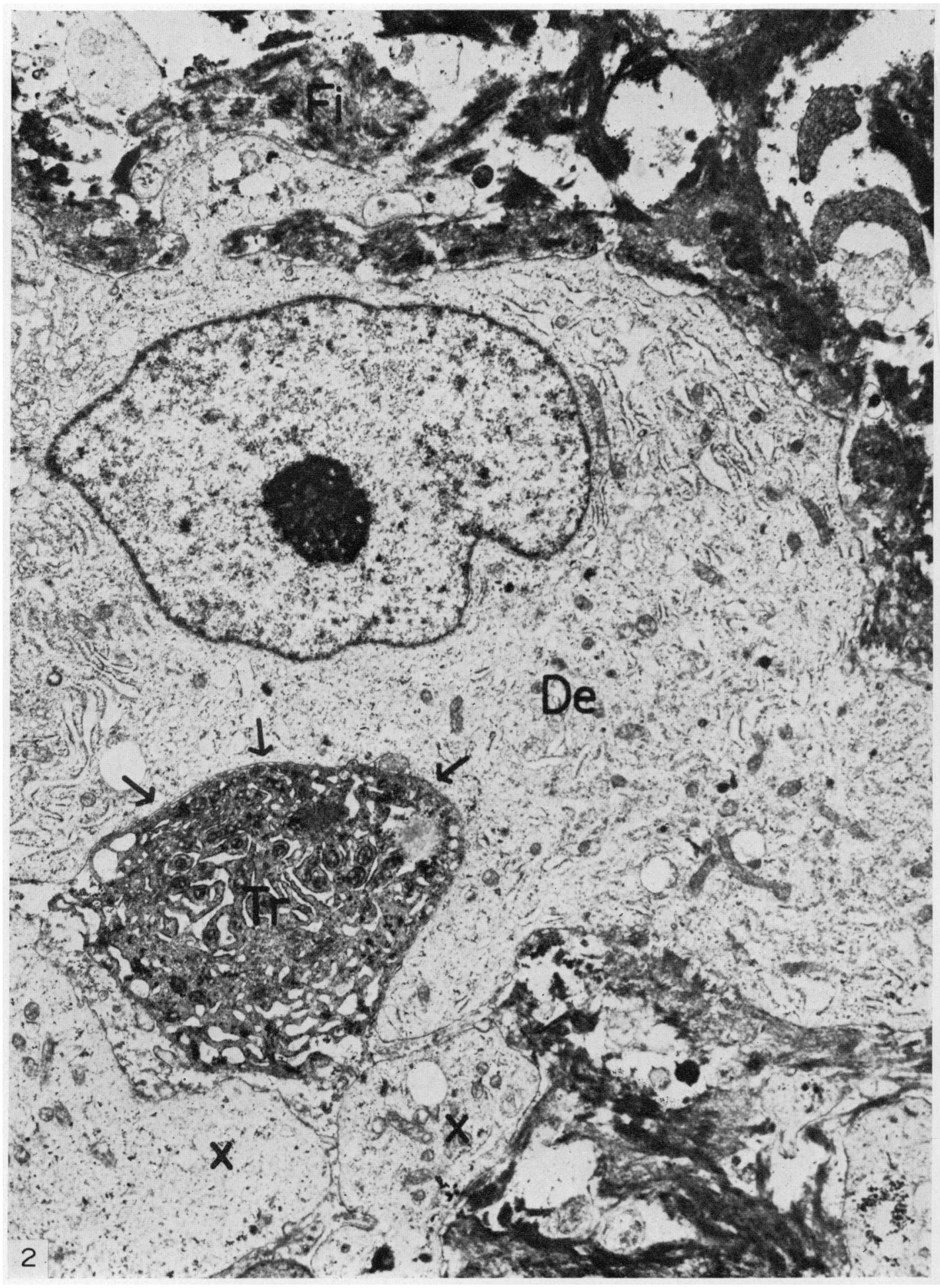




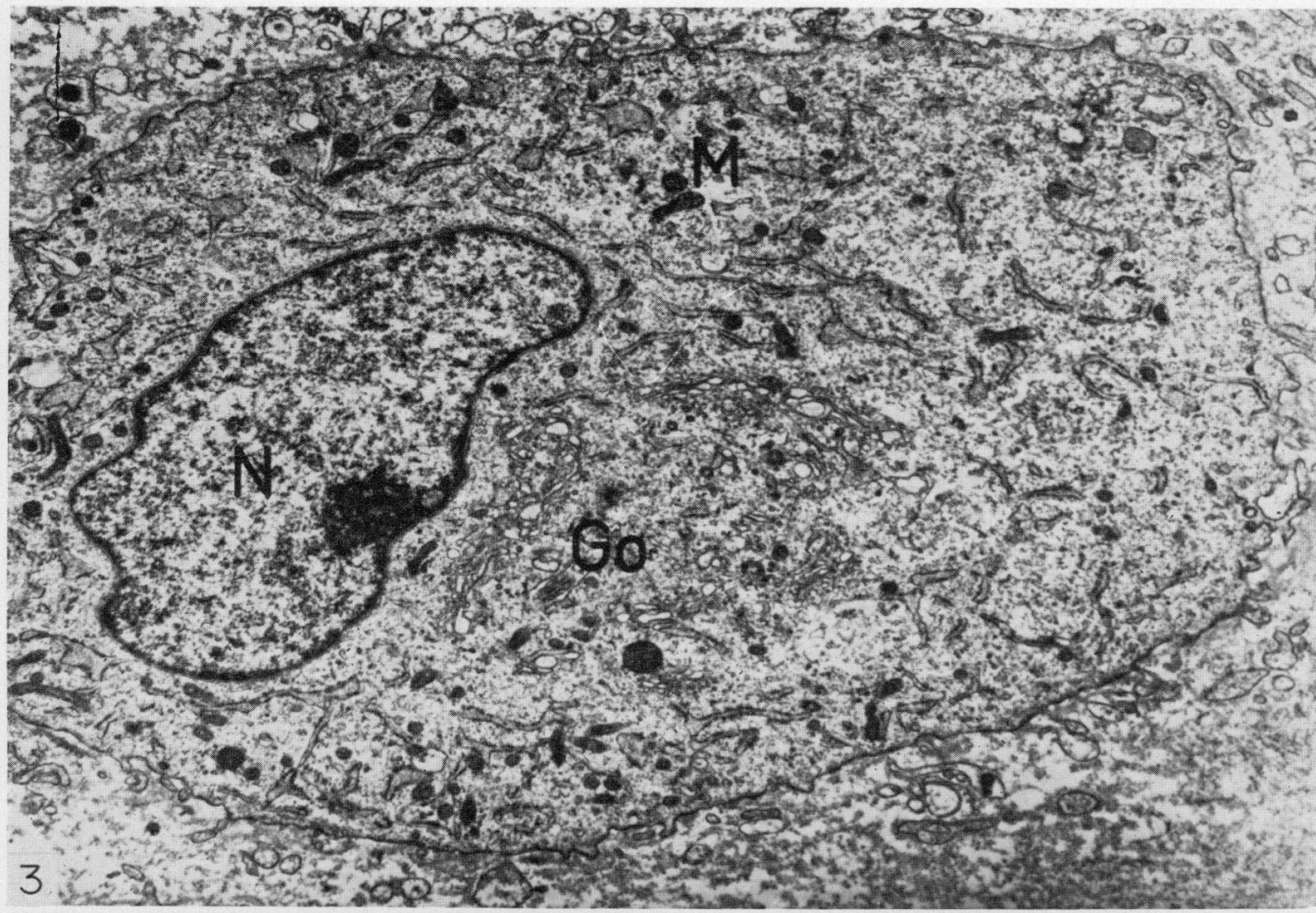

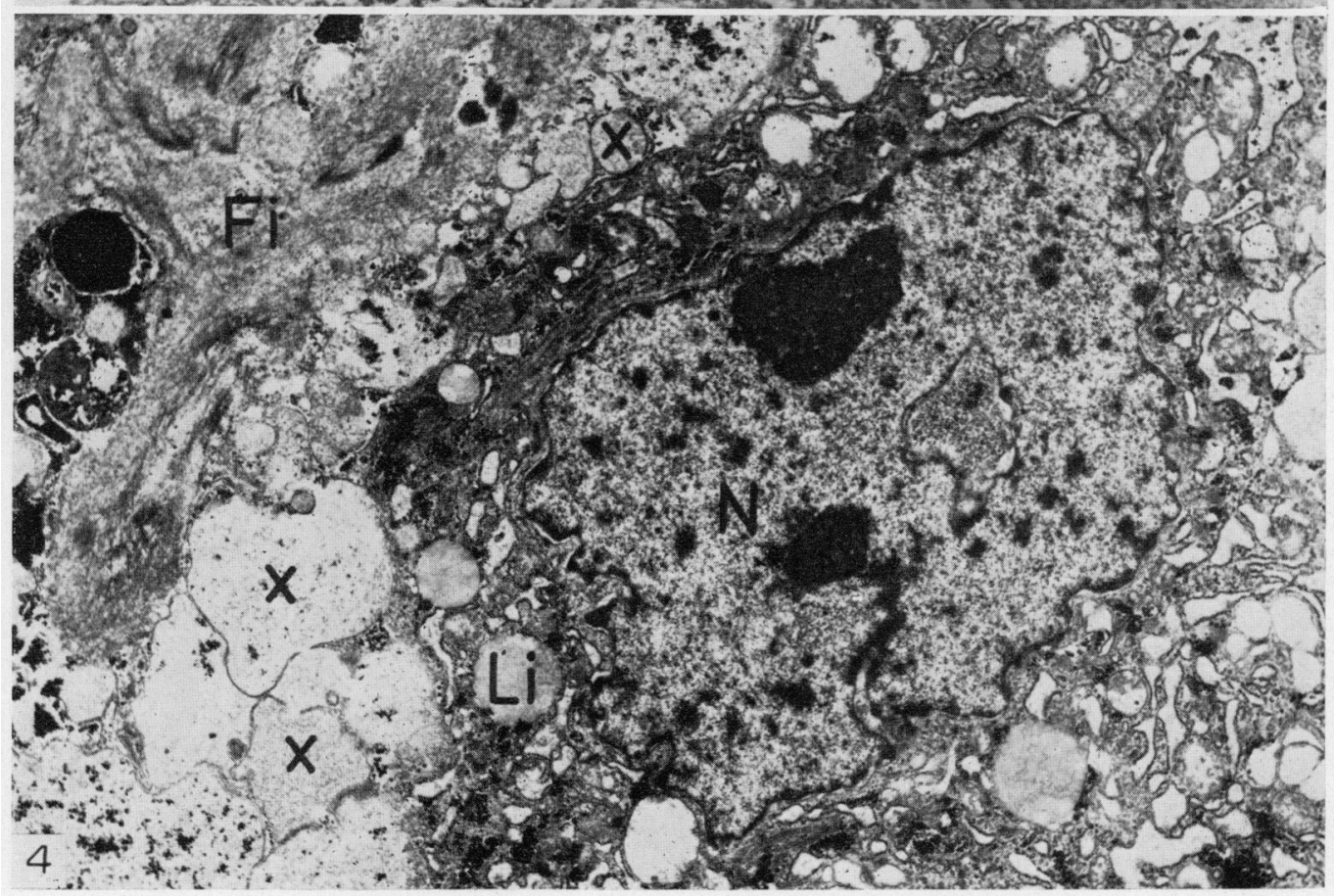




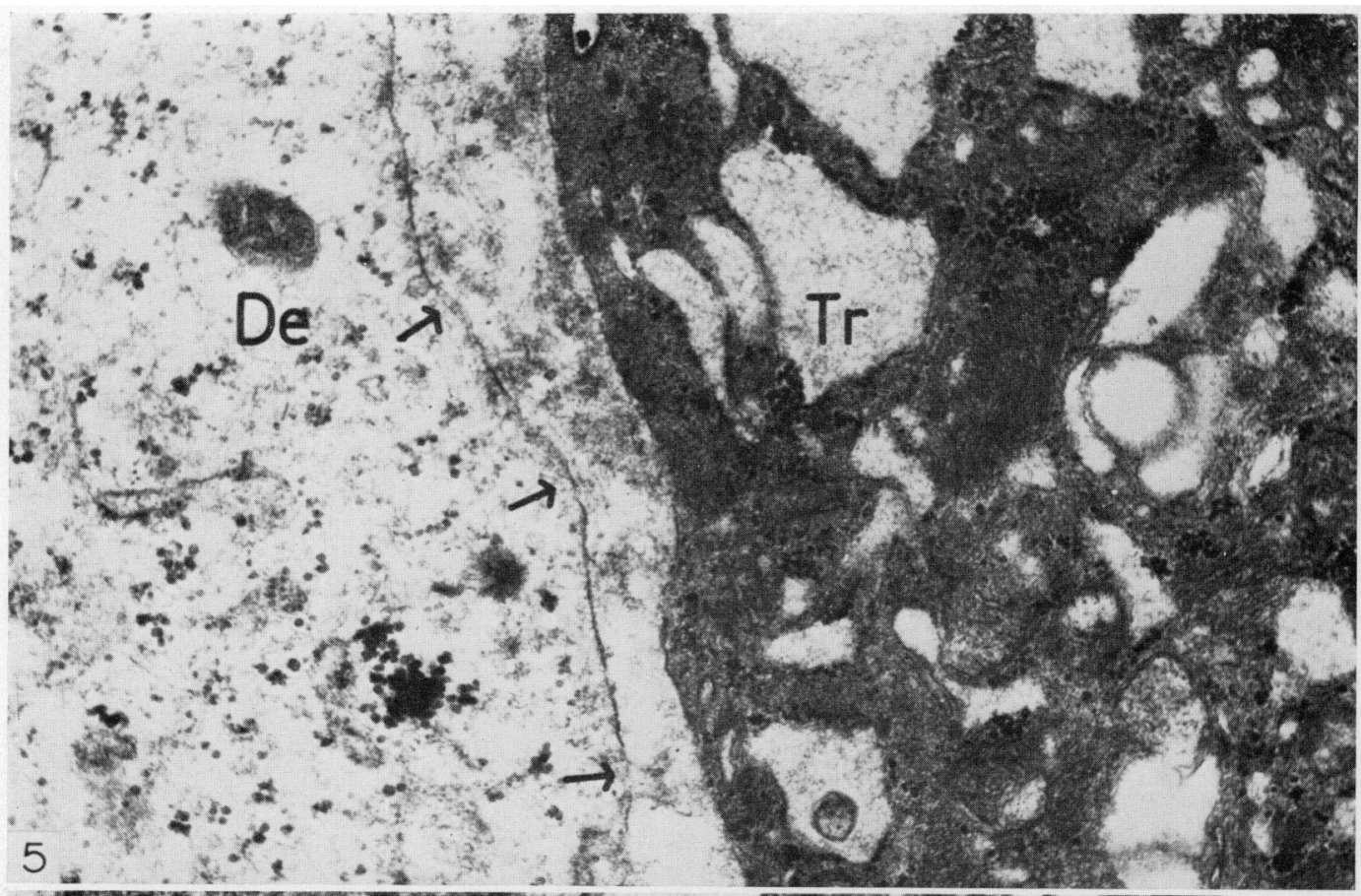

7. be

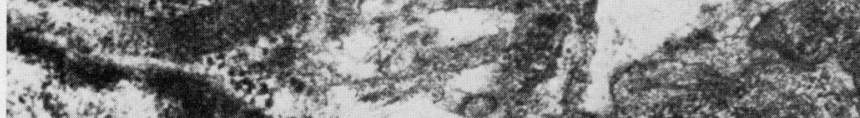

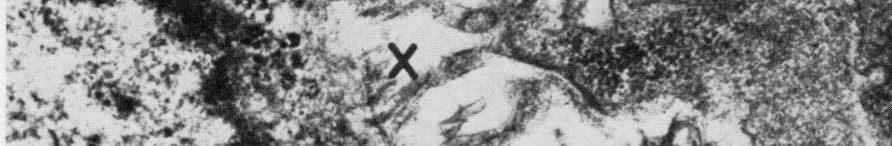

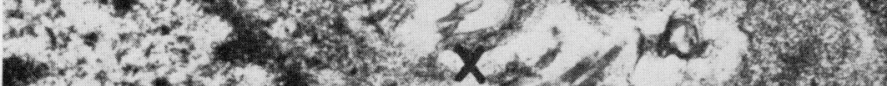

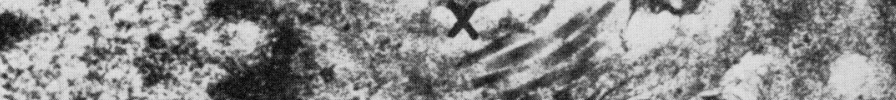

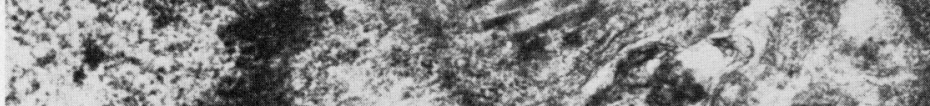

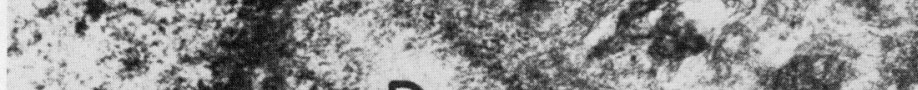

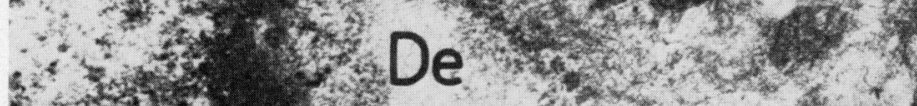

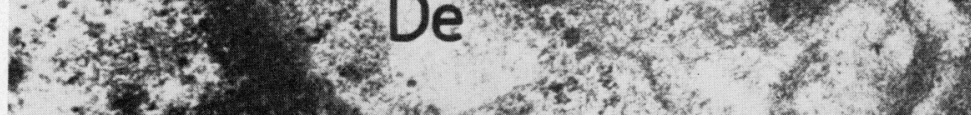

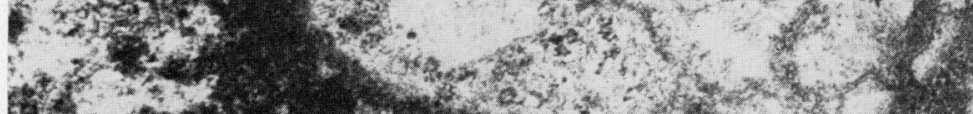

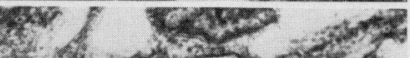
to: 


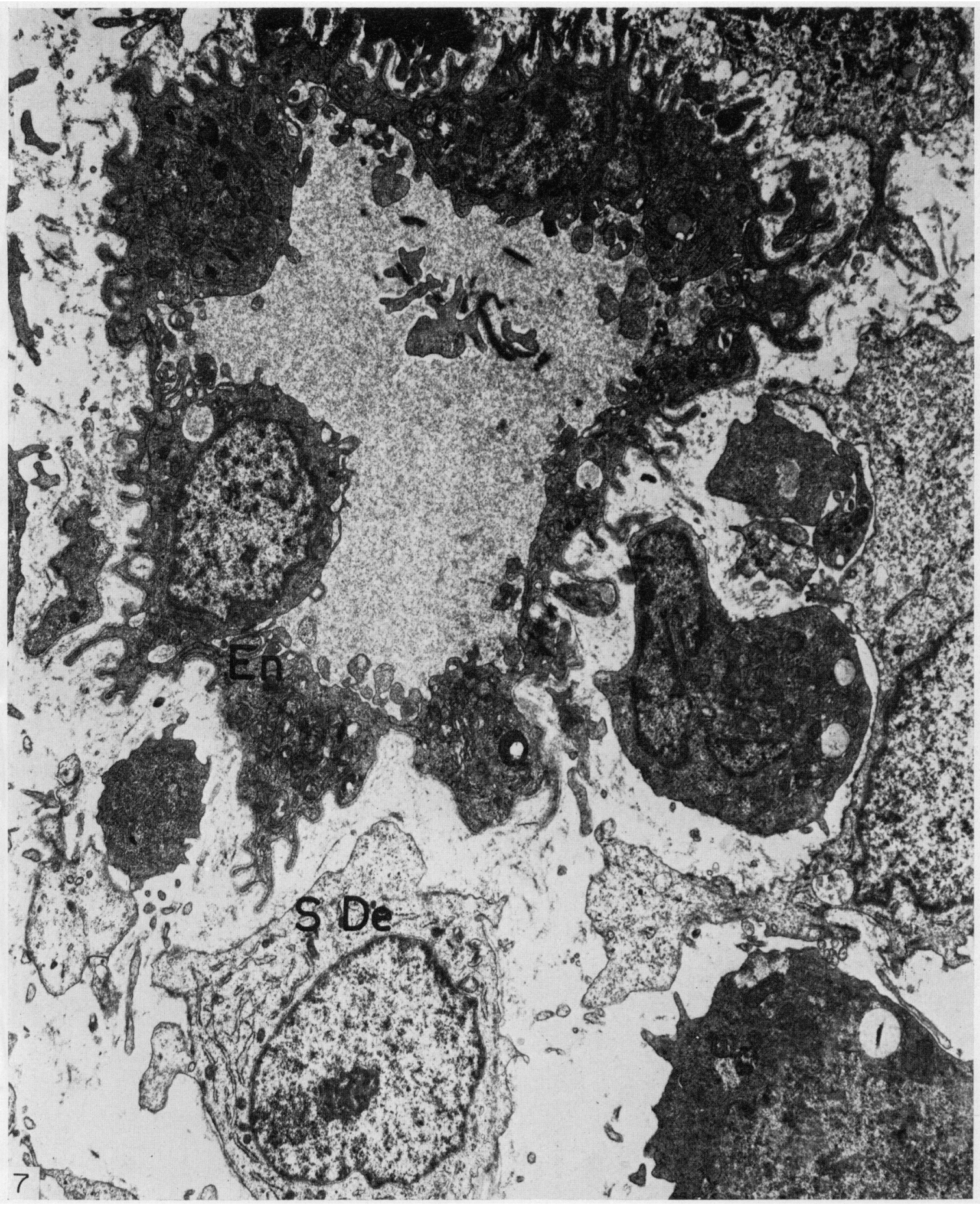




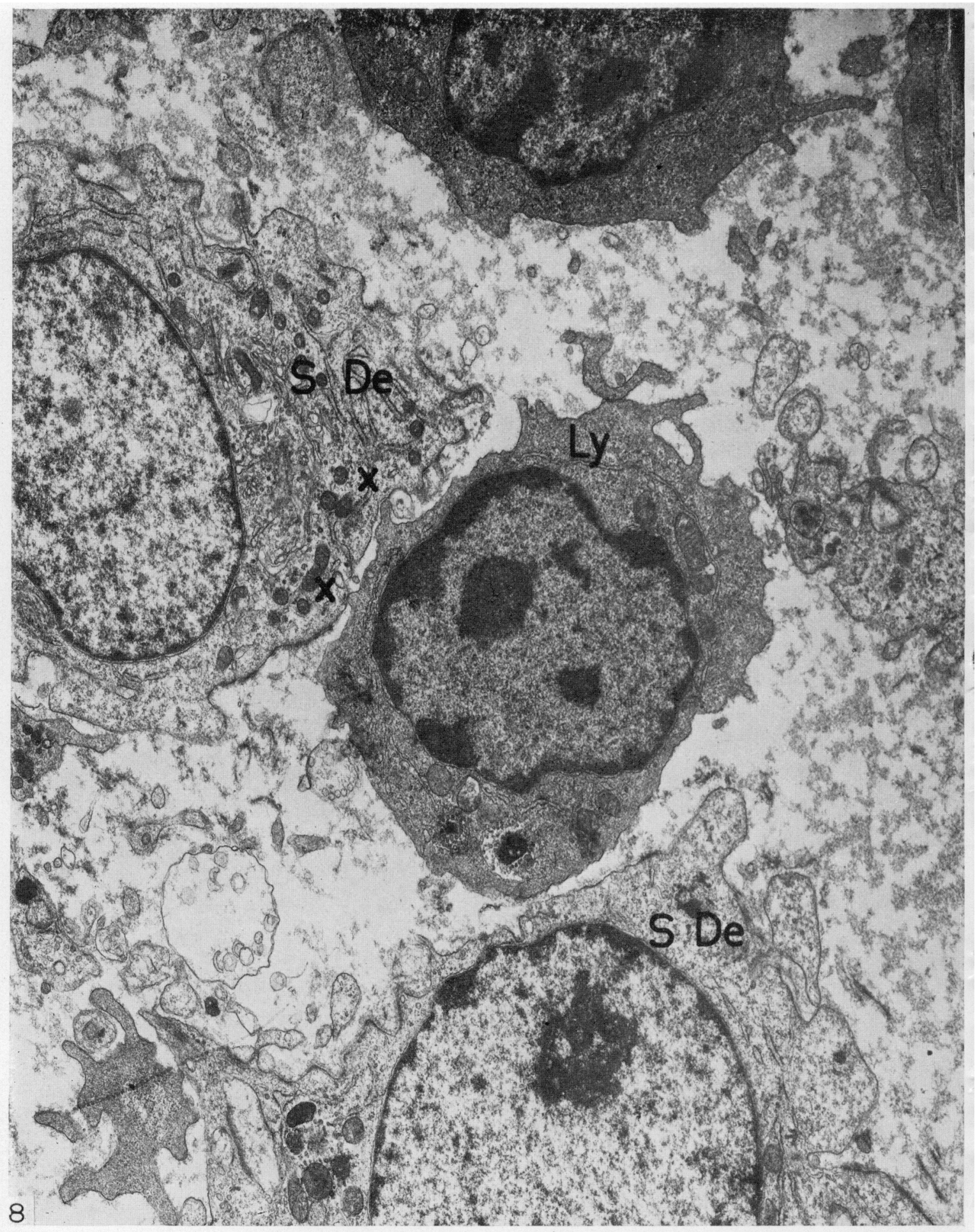




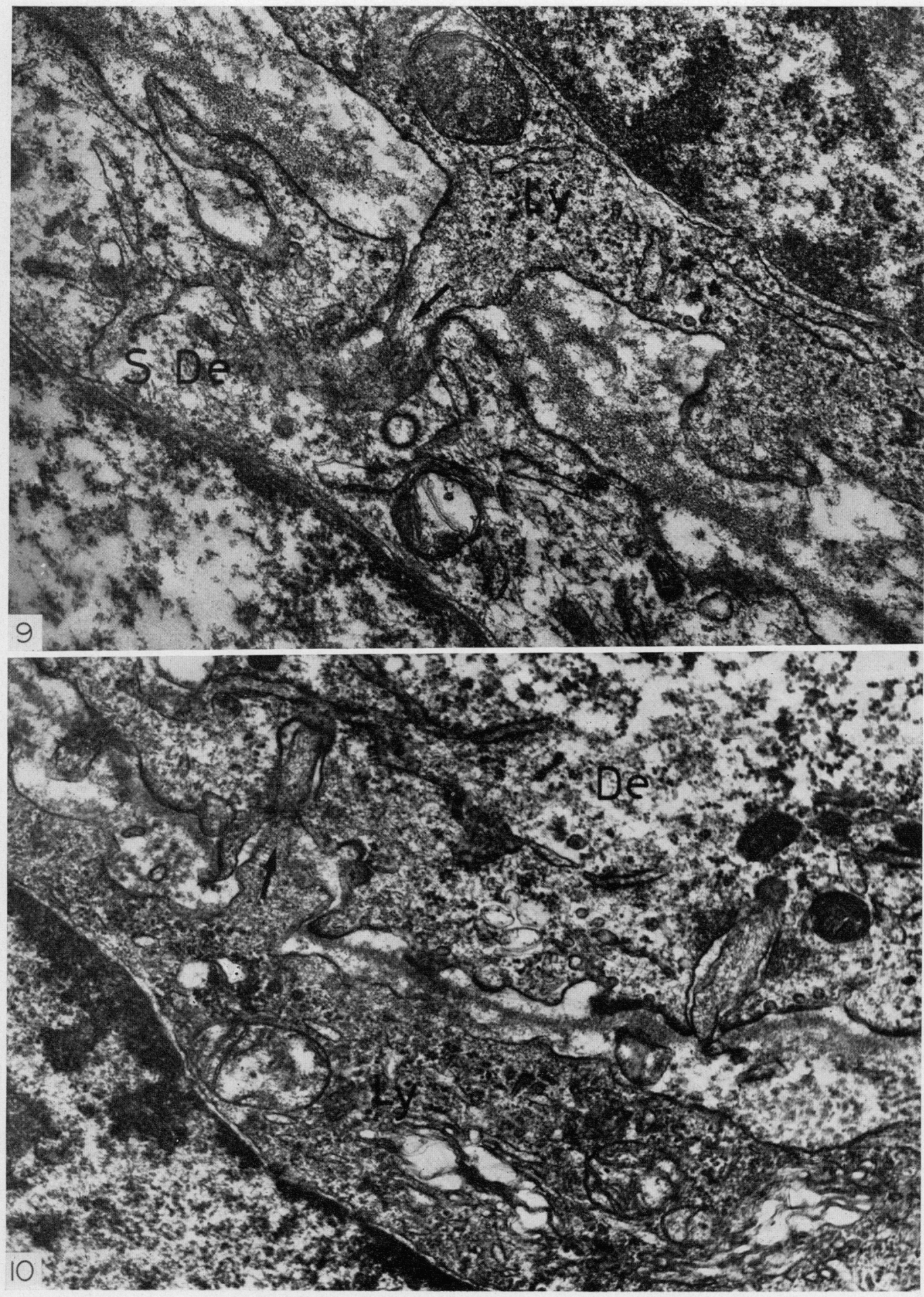




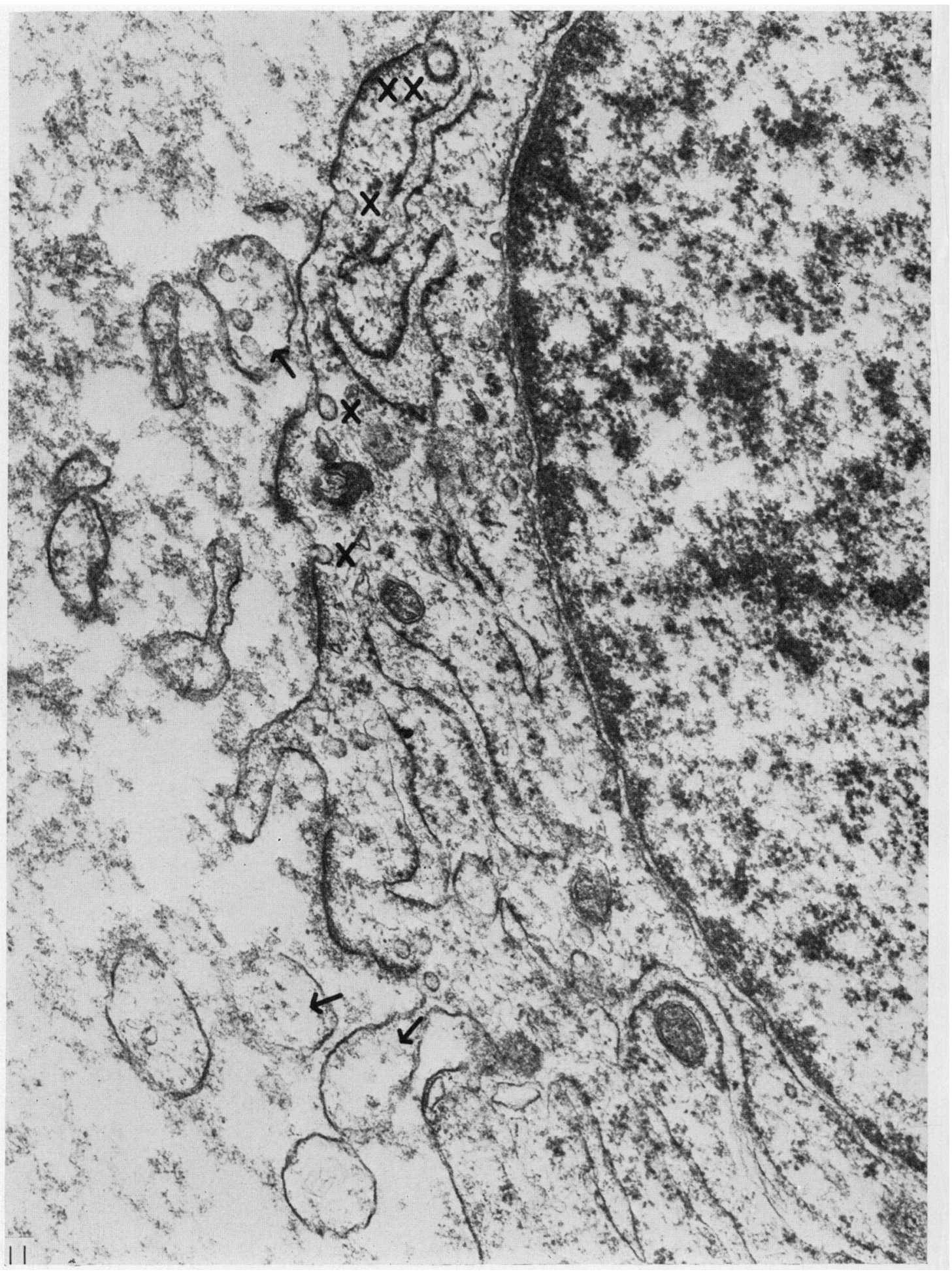


Edwards \& Purdy, 1971) fuse with the uterine epithelium in the same manner. The intimacy of decidua and trophoblast in guinea-pig placenta has already been stressed by Wynn (1964, 1967a, b). He suggested that decidua and trophoblast on the basal plate of human placentae are separated by fibrinoid and degenerated elements of decidual and trophoblastic origin, although no fibrinoid was found in the deciduotrophoblastic space in some species with types of placentation other than haemochorial. Wynn (1969) also indicated that trophoblastic cells might come into contact with the decidua at the beginning of haemochorial placentation, as judged from observations on later phases of pregnancy, although he insisted that a non-cellular barrier was established "not later than the time at which a homograft is normally rejected". Larsen (1961) failed to observe any fibrillar deposits between decidua and trophoblast in rabbit placentae, nor were such deposits detected during early pregnancy in mice (Potts, 1968). The fibrinoid layer was found to be discontinuous between decidual and trophoblastic cells in rat and mouse placentae in late pregnancy, and the two types of cell were in intimate contact at numerous points at the deciduotrophoblastic interface (Martinek, 1970, 1971).

The origin of fibrillar material in the deciduotrophoblastic area has been much disputed. Terms such as fibrin, fibrinoid and fibrin-like material have been proposed without basing any of these on clear histochemical criteria. In the present work, the term 'fibrillar material' is used, not in any histochemical sense, for the sum of fibrillar elements located at the junctional area, and intercellular material was found to be randomly distributed between the decidual and trophoblastic cells. Mouse placental fibrinoid was reported to be of trophoblastic origin (Kirby, Billington, Bradbury \& Goldstein, 1964; Kirby \& Bradbury, 1965), although a decidual contribution has also been postulated (Wynn, 1969). The trophoblastic cells of mice did not produce any fibrillar material when transplanted under the kidney capsule (Simmons, Cruse \&

\section{EXPLANATION OF PLATES 5 TO 8}

PLATE 5

Fig. 7. Pericapillary area of pregnant human endometrial connective tissue. Small decidual cells (S De) are seen together with the ordinary connective tissue cells. The basal contours of the endothelial cells (En) lining the capillary lumen are highly undulated. $\times 6500$.

PLATE 6

FIG. 8. Typical small human decidual cells (S De) having close structural relations $(x)$ between lymphoblasts (Ly). The cells are loosely arranged. No distinct fibrillar deposits exist among the small decidual cells. $\times 8000$.

\section{PLATE 7}

Frg. 9. Close relationship between a small human decidual (S De) and a lymphoblastic cell (Ly). Note the projection (arrowed) from the lymphoblast into the decidual cell. $\times 40,000$.

Frg. 10. Another example of the close association between a human lymphoblastic (Ly) and decidual cell; a lymphoblastic projection (arrowed) can be seen. $\times 40,000$.

\section{PLATE 8}

Fig. 11. Detail of the peripheral cytoplasm of the small human decidual cell. Tiny, club-like cytoplasmic protrusions are seen to be detached from the cell surface (arrows). Uncoated vesicles $(x)$ are frequent and attached to the cell membrane at points between the membrane thickenings. A protein-coated vesicle $(x \times)$ is located in the vicinity of the profiles of peripheral tubuli of granular endoplasmic reticulum and is connected to the cell membrane. $\times 48,000$. 
McKay, 1967). The intercellular material of the junctional zone in humans was shown to be composed of fibrin, fibrinogen or aged fibrin of maternal origin together with cellular remnants, as judged by immunofluorescence using antisera against fibrin and fibrinogen (Moe, 1969a). Maternal plasma evidently seeped through and precipitated in the intercellular space, and then completely separated decidua and trophoblast (Moe, 1969b). There is no doubt that maternal immunoglobulin is associated with trophoblast during human pregnancy, for it has been detected by immunofluorescence on this tissue and can be extracted and purified (Faulk et al., 1975). Several other components of serum were also extracted from this site.

A close association of small developing decidual cells with lymphoblasts was detected around the precapillary arterioles and capillaries. The extensions of lymphocytes into close association with decidual cells might arise during the normal movement of lymphocytes into the implantation site, although some form of deciduo-lymphoblastic interaction might occur as decidual cells differentiate in the endometrium. In guinea-pigs, modified thymic lymphocytes known as 'Kurloff cells' evidently donate to trophoblastic cells various mucoproteins or mucopolysaccharides capable of killing macrophages (Marshall, Swettenham, Vernon-Roberts \& Revell, 1971). Migration of lymphocytes and monocytes towards the trophoblast in the deciduotrophoblastic area has been reported in women (Hamilton \& Boyd, 1960) and other mammals (Kirby, 1970; Mulnard, 1970), and endometrial granulocytes were found in human decidua (Dallenbach-Hellweg \& Nette, 1964). Lymphocytes might enter the endometrium as a result of the inflammatory nature of implantation rather than as a specific response to the embryo, although distinct shifts in lymphocyte populations have been reported during pregnancy, as shown by the decrease in size of the thymus gland (Nelson, Hall, Manuel-Limson, Friedburg \& O'Brien, 1967; Maroni \& de Sousa, 1973), an increase in the size of peripheral lymph nodes draining the uterus (Maroni \& de Sousa, 1973; Beer \& Billingham, 1971) and changes in lymphocyte populations in the thymus, spleen and peripheral lymph nodes (Howe, 1975). In the mare, a pronounced lymphocytic invasion destroys the trophoblastic outgrowths known as endometrial cups, and in a manner resembling the rejection of an allogeneic graft (Allen \& Moor, 1972). Maternal lymphocytes are sensitized to fetal antigens during pregnancy in mice (Sören, 1967). Lymphocytes are believed to form associations with macrophages and other cells (Marchesi \& Gowan, 1963; McFarland \& Heilman, 1965), and migrate freely through the basal lamina of epithelial tissues, and perhaps through the cytoplasm of the vascular epithelium, without impairing the structural integrity of these tissues (Zweifach, 1965).

Evidence in several species now fails to support the notion of a physical barrier separating maternal and fetal components, and the close association between cells in the deciduotrophoblastic complex raises doubts about concepts involving electrical repulsion between fetal and maternal cells. Barriers considered to modify interaction between mother and fetus have included the weak antigenicity of trophoblast cells (Edwards, Howe \& Johnson, 1975), or the formation of an intermediate layer through the fusion of maternal and fetal cells. The rôle of the decidual cells and their secretions must also be considered, for various 
kinds of graft can survive long periods in uteri after decidualization has occurred (see Watnik \& Russo, 1968), but not before (see Poppa, Simmons, David \& Russel, 1964). The decidua may limit trophoblastic invasion during pregnancy (Kirby, 1970) although the situation in ectopic sites such as the testis, brain or abdominal organs is not clear since decidualization is likely to be weaker than in the uterus.

\section{AGKNOWLEDGMENTS}

We wish to thank Professor C. R. Austin and Professor V. E. Cosslett for their encouragement, and the World Health Organization and Ford Foundation for financial support.

\section{REFERENCES}

Allen, W. R. \& Moor, R. M. (1972) The origin of the equine endometrial cups. F. Reprod. Fert. 29, 313-316.

BeER, A. \& Billingham, R. E. (1971) Immunobiology of mammalian reproduction. Adv. Immunol. 14, $2-84$.

Dallengach-Hellweg, G. \& Nette, G. (1964) Morphological and histochemical observations on trophoblast and decidua of the basal plate of human placenta at term. Am. F. Anat. 115, 309-326.

Edwards, R. G., Howe, C. W. S. \& Johnson, M. H. (1975) (Eds.) Immunobiology of Trophoblast. Cambridge University Press.

ENDERs, A. G. (1968) Fine structure of anchoring villi of the human placenta. Am. F. Anat. 122, 419-451.

ENDERs, A. C. \& SCHLAFKe, S. (1971) Penetration of the uterine epithelium during implantation in the rabbit. Am. F. Anat. 132, 219-239.

Faulk, P., Trenchev, P., Dorling, J. \& Holborow, E. J. (1975) Antigens on post-implantation placentae. In Immunobiology of the Trophoblast. Eds. R. G. Edwards, C. W. S. Howe and M. H. Johnson. Cambridge University Press. (In press).

FAwcETt, D. W. (1966) An Atlas of Fine Structure. The Cell. Its Organelles and Inclusions. W. B. Saunders, Philadelphia and London.

Hamilton, W. J. \& Boyd, J. D. (1960) Development of human placenta in the first three months of gestation. F. Anat. 94, 297-328.

Howe, C. W. S. (1975) Lymphocyte physiology during pregnancy. In Immunobiology of Trophoblast. Eds. R. G. Edwards, C. W. S. Howe and M. H. Johnson. Cambridge University Press. (In press).

KIRBy, D. R. S. (1970) Immunological aspects of implantation. In Ovoimplantation, Human Gonadotropins and Prolactin, pp. 86-100. Eds. P. D. Hubinont, F. Leroy, C. Robyn and P. S. Leleux. Karger, New York.

Kirby, D. R. S., Billington, W. D., Bradbury, S. \& Goldstein, D. J. (1964) Antigen barrier of the mouse placenta. Nature, Lond. 204, 548-549.

KIRBY, D. R. S. \& BRADBURY, S. (1965) The hemo-chorial mouse placenta. Anat. Rec. 152, 279-281.

LARSEN, J. F. (1961) Electron microscopy of the implantation site in the rabbit. Am. F. Anat. 109, 319-334.

LaWn, A. M., Wilson, E. W. \& Fins, C. A. (1971) The ultrastructure of human decidual and predecidual cells. F. Reprod. Fert. 26, 85-90.

McFarLand, W. \& Heilman, D. H. (1965) Lymphocyte foot appendage: its role in lymphocyte function and in immunological reactions. Nature, Lond. 205, 887-888.

MARChesi, V. T. \& Gowan, J. L. (1963) The migration of lymphocytes through the endothelium of venules in lymph nodes: an electron microscope study. Proc. $R$. Soc. Lond. B, 159, 283-290.

MARONI, E. S. \& DE SousA, M. A. B. (1973) The lymphoid organs during pregnancy in the mouse. A comparison between a syngeneic and an allogeneic mating. Clin. exp. Immunol. 13, 107-124.

Marshall, A. H. E., Swettenham, K. V., Vernon-Roberts, B. \& Revell, P. A. (1971) Studies on the function of the Kurloff cell. Int. Archs Allergy appl. Immun. 40, 137-152.

Martinex, J. J. (1970) Fibrinoid and fetal-maternal interface of the rat placenta. Anat. Rec. 166, $587-603$.

MARTINEK, J. J. (1971) Ultrastructure of the deciduotrophoblastic interface of the mouse placenta. Am. F. Obstet. Gynec. 109, 424-431.

Milzonig, G. (1962) Further observations on a phosphate buffer for osmium solutions in fixation. Proc. 5th Int. Congr. Electron Microse. Vol. II, p. 8. Ed. S. S. Breese. Academic Press, New York and London. 
Mor, N. (1969a) The deposits of fibrin and fibrin-like material in the basal plate of the normal human placenta. Acta path. microbiol. scand. 75, 1-17.

Moe, N. (1969b) Deposits of fibrin and plasma proteins in the normal human placenta. An immunofluorescence study. Acta path. microbiol. scand. 76, 74-88.

Mulnard, J. G. (1970) Aspects de l'activité phagocytaire du trophoblaste de la souris au début de l'ova-implantation. In Ovoimplantation, Human Gonadotropins and Prolactin, pp. 9-17. Eds. P. O. Hubinont, F. Leroy, C. Robyn and P. S. Leleux. Karger, New York.

Nelson, J. H., Hald, J. E., Manuel-Limson, G., Freidburg, H. \& O'Brien, F. J. (1967) Effect of pregnancy on the thymolymphatic system. I. Changes in the intact rat after exogenous HCG, estrogen and progesterone administration. Am. 7. Obstet. Gynec. 98, 895-899.

Poppa, G., Simmons, R. L., David, S. D. \& Russeli, P. S. (1964) The uterus as a recipient site for parathyroid homotransplantation. Transplantation, 2, 496-502.

Potтs, D. M. (1968) The ultrastructure of implantation in the mouse. 7. Anat. 103, 77-90.

Reynolds, E. S. (1963) The use of lead citrate at high $\mathrm{pH}$ as an electron-opaque stain in electron microscopy. 7. Cell Biol. 17, 208-212.

Simmons, R. L., CRuse, V. \& MCKAY, D. G. (1967) The immunological problem of pregnancy. II. Ultrastructure of isogeneic and allogeneic trophoblastic transplants. Am. J. Obstet. Gynec. 97, 218-230.

SöREN, L. (1967) Immunological reactivity of lymphocytes in multiparous females after strain specific matings. Nature, Lond. 213, 621-622.

Steptoe, P. C., Edwards, R. G. \& Purdy, J. M. (1971) Human blastocysts grown in culture. Nature, Lond. 229, 132-133.

TACHI, S., TACHI, C. \& LindnER, H. R. (1970) Ultrastructural features of blastocyst attachment and trophoblastic invasion in the rat. $\mathcal{7}$. Reprod. Fert. 21, 37-56.

WAtnik, A. S. \& Russo, R. A. (1968) Survival of skin homografts in uteri of pregnant and progesteroneestrogen treated rats. Proc. Soc. exp. Biol. Med. 128, $1-4$.

Wynn, R. M. (1964) Ultrastructure of the deciduotrophoblastic junction of the guinea-pig. Am. 7 . Obstet. Gynec. 90, 690-693.

Wynn, R. M. (1967a) Fetomaternal cellular relations in the human basal plate. An ultrastructural study of the placenta. Am. F. Obstet. Gynec. 97, 832-850.

Wynn, R. M. (1967b) Comparative electron microscopy of the placental junctional zone. Obstet. Gynec., N.X. 29, 644-661.

Wynn, R. M. (1969) Non-cellular components of the placenta. Am. J. Obstet. Gynec. 103, 723-739.

ZweIfach, B. W. (1965) Microvascular aspects of tissue injury. In The Inflammatory Process, chap. 4, pp. 161-196. Eds B. W. Zweifach, L. Grant and R. T. McGluskey. Academic Press, New York. 